\title{
PERSPECTIVES ON EUROPEAN UNIFICATION ${ }^{\dagger}$
}

\author{
DeAN RusK*
}

When one lives with an idea for twenty-five years, in terms of hope and aspiration, it is very hard for him to realize that maybe it just might finally become reality. The notion of a broad European Community came into the minds of American leaders at a very early stage. In the immediate post-war period I would suggest that the United States was somewhat ahead of our friends in Europe on this idea, for several reasons. First was the rather naive and sentimental notion that we are the United States of America: our's is a good system and it works well, and it would be good for the Europeans to have this on their side of the Atlantic. On a much more sophisticated level, we felt that a unified Europe would probably take care of any possible resurgence of the German question. In those days, it will be recalled, there was some concern about that. It was the Western Allies who were concerned about Articles 107 and 53 of the United Nations Charter, having to do with the enemy countries of World War II, because at that time we were not quite sure in which way Germany would develop. We thought that a unified Europe would at long last prevent the emergence of a war within Western Europe, for twice in this century we have been drawn into a world war which had originated within that area.

Then, as events unfolded in the late 1940's, we also became concerned about the defense of Europe over against Eastern Europe. I know there has been a lot of revisionist history written recently, but I recall that in $x 945$ we demobilized almost literally overnight, and almost completely. By 1946 we did not have a single division in our Army, nor a single air group in our Air Force, which was combat-ready. Our defense budget for 1947 had declined to almost ro billion dollars. It should be remembered that Joseph Stalin was the fellow who said: "The Pope? How many divisions does he have?" He could look out across the West and not see any divisions. So he tried to keep the northwestern frontier of Persia. He demanded the two eastern provinces of Turkey and a share in the control of the Dardanelle Straits. He ignored key elements in the peace treaties for Eastern Europe. He arranged the coup d'etat in Czechoslovakia, blockaded Berlin, and sent the North Koreans into South Korea. These events were the origin of the Cold War. The revisionist historians can write until all the ink in' the world is used up and they can't change that.

We began to feel that a unified Europe would be important for the sake of its own defense-for the defense of the West, which was crucially vital to the United States, against the possibility of further threats, pressures, or incursions from Eastern

\footnotetext{
tThe following informal remarks were delivered at the Duke Institute on the Expansion of the Common Market, April ז4, 1972. Selections from the discussion period which followed the presentation have also been reproduced.

- Secretary of State, 196r-69; presently Professor of Law, University of Georgia.
} 
Europe. At that time the United States made two major contributions that had a great deal to do with launching the notion of European unity, that is, NATO and the Marshall Plan. Our European friends were rather astonished that the United States was willing to move in these two directions. In view of the background of our relationship, I think they would have been very reluctant to ask this country to do so, but the U.S. volunteered to undertake these efforts. Notably, the Marshall Plan brought their heads of state together because, it will be recalled, the Western' European participants had a great deal of work to do in preparing and implementing the Plan. And NATO was also a forum in which the Western European nations met. While this was still under the leadership of the United States, it did tend to bring somewhat greater cohesion to the European Community. By and large, however, I think that our interest in' European unity was ahead of the political possibilities for these Western European countries, which were preoccupied with their own rebuilding and in healing the wounds of World War II. They were all countries of ancient traditions and strong nationalistic feelings. They were just not able to move quite as fast as we would have liked because, after all, it was they who were supposed to make such fundamental changes, not the United States. But with the help of a good many Europeans, the idea continued to grow and in 1957 the Treaty of Rome was signed.

One of the important elements in this development was the fact that during World War II the United States and Great Britain had been the closest companions in great enterprises, chiefly in the waging of the war. The U.S. and Britain developed a truly special relationship. They were the only ones in the then sa-called free world who had the capacity to act against the Axis Powers. France did not have the capability to be a member of that group, to the later dismay of General DeGaulle. Our special relationship tended for a good many years to lead the British to feel that they would be better off to maintain an independent position vis-à-vis Europe rather than become a genuine member of the European Community. Over time, that special relationship tended to wither away; for a great variety of reasons, the U.S. and Britain were no longer partners in' great enterprises on a bilateral basis. That loosening trend between the "Anglo-Saxons" was very important to what has happened in the last few years.

At the end of the I950's, we entered the DeGaulle era-a major detour in the process of European unity. What does a mere mortal say about Charles DeGaulle? I had many talks with him, but I wouldn't say that they were exchanges of views. Talking with DeGaulle was like crawling up a mountain side on your knees, opening a little portal at the top, and waiting for the oracle to speak. There was no give and take of ideas. I have decided long since that I will never write my memoirs, and I don't intend to write them indirectly or piecemeal in the present circumstances. But I have no doubt that President DeGaulle's primary idea was that France should be the spokesman for Western Europe. He looked upon France as the principal member of the Western European Community. There was a 
Germany, of course, whose economy and power should be respected, but which, he felt, ought clearly to be in' a secondary position to France. He did not look upon Italy as an important member of the European Community. The Benelux Countries were negligible in his point of view. And then, he said, there was Britain. Britain is not European, and it is fatally infected by its close relationship with the United States. Thus, he had some very strong ideas that blocked further progress toward an enlarged Common Market for about a decade.

It was very hard to do anything about this lack of progress during the DeGaulle era. I remember talking many times with his foreign minister. When a particular question would come up, there were occasions when I would say: "Well now, you speak first, because if you speak first, I might be able to agree with you, but if I speak first, you've got to disagree." That reflects some of the problems we had during the special period of General DeGaulle. My favorite quotation of General DeGaulle is the one in which he said: "My personal tragedy is that I have respect only for those who stand up to me, but those," he said, "I find intolerable." There was a problem concerning the role which the United States ought to play-what our attitude toward the Common Market during the DeGaulle period should be. I talked with a number of our Western' European colleagues, who were very much interested in the Common Market, about how they thought the United States ought to react-what we ought to say; what effort we ought to try to make; whether we ought actively to encourage further progress toward European unity, or let the initiative come from Europe. Generally, their attitude was that we should not put ourselves in the front of the effort for unification. They said: of course, you can say you are in favor of the Common Market, but you should not carry on' a crusade for this. Otherwise, you might stiffen DeGaulle's attitude. In essence, it was their belief that nothing would be done until DeGaulle left office.

I have a deep concern for the unification of Europe on the broadest basis of world politics. In particular, I am concerned about the isolationism of Europe. The Untied States is in a mood of withdrawal. This has been encouraged by the preceding mood of withdrawal in Western Europe. This is not simply their giving up their colonial empires; rather it is their failure to draw together to assert a leading role in matters of world affairs which we would have thought were of vital interest to them. For example, in NATO Foreign Ministers' meetings, it was extremely difficult to get the European Ministers interested in the Middle East, which is twenty minutes flying time from NATO countries, or in North Africa. I once reminded the Ministers that the territory covered by the NATO agreement reached all the way to the Bering Sea and that they had better give some attention to China. But they seemed to think it was ridiculous to suggest that NATO had any purpose other than the defense of Europe. I have myself regretted the relative isolationism of Western Europe from an active and leading participation in world affairs.

If the notion of collective security is rapidly eroding in this country, and I think it is, it is for two reasons. One is that the United States has taken more than 600,000 
killed and wounded since the end of World War II, and it is not unreasonable for the American people to say: look, if collective security is going to require 50,000 killed every decade, we ought to look for a better answer. But the second reason for the development of this view in America is that the other members of the so-called free world have tended to sit on their hands and let the United States carry this responsibility relatively alone. The United States supplied ninety per cent of the non-Korean forces in Korea, and eighty per cent of the non-Vietnamese forces in Viet Nam. The American people, therefore, wonder just how collective this notion of collective security really is.

Because the idea of collective security is now eroding, what Europe does within the next five to ten years could have a great influence on what the American people are able and willing to do. For example, who is going to sit at that Superpower Table ten years from now? The Soviet Union; the Peoples' Republic of China. Unless there is a united Europe prepared to sit at that table, then the United States is not going to be sitting there. We are not going to play that role. In that situation there are going to be only two superpowers. Already one sees pressing demands for far-reaching unilateral disarmament in the United States, as though we've never been down that trail before; but we've been down it several times. So I am concerned about the expanded Common Market moving rapidly to establish a degree of unity and cohesion and a world view which will bring Europe back into the world picture in a way that will make it possible for the United States to take a role which I consider essential if we are to avoid World War III.

The United States has recognized all along that when the Common Market is expanded there will be some economic pains for us. There are going to be some difficult trade negotiations, an'd there will be a good deal of dissatisfaction on both sides, and perhaps some acrimony. Even though this might be the case, we have also supposed that the political benefits, and benefits to world security, of a unified Europe would far outweigh the difficulties we might have at the economic level. Thus, I hope that Britain will play an active and leading role in the Common Market and take with it whatever remains in terms of a special relation'ship with the United States. Hopefully, we can build on that for a genuine special relationship with a unified Europe and become real partners on the basis of each having its own views and developing its own interests, but finding that their interests largely coincide. We can be partners not in terms of the kind of domination' that existed at the end of World War II, but partners in a general program of mutual commitments, because we have generally the same kind of goals.

$$
\text { ***** }
$$

QUESTION: Do you foresee the Common Market, once it has stabilized, increasing further in size? Also, do you foresee the development of other common markets?

I would be a little surprised if the Common' Market grew much beyond the 
present addition of the four members. But in terms of other unions, I think we will have to work out special trading arrangements with other nations or groups of nations of a sort that could cause us some problems. With respect to some of these, we are going to have to bargain pretty hard. I would hope that our Latin American colleagues could move somewhat faster toward their own common market. The Latin Americans were rather surprised during the I960's when we told them that as far as we were concerned, we would be in favor of a Latin American Common Market. They had supposed that our attitude was to divide and rule. And yet, for a variety of reasons, they have thus far been moving slowly. I think that the Latin Americans will suffer if they are the only important group of nations that are not involved in some sort of collective arrangements. Many of the African countries will have their special arrangements with the Common Market. The Latin American countries therefore might suffer in the absence of collective bargaining power on the terms of trade.

QUESTION: Were you surprised at the rapidity of change in the French position after DeGaulle left power?

Not really, because only DeGaulle could be DeGaulle. If anybody else tried to play that role, he would be a kind of a comic character. I thought there would be some important changes in policy by France vis-à-vis its neighbors in Europe after the departure of DeGaulle from government. But they haven't changed all that much. For example, they have not taken their seat at the disarmament talks in Geneva, and they haven't resumed full participation in NATO. There still are some questions about how much they are willing to cooperate within the Ten. But my guess is that France is now willing to move toward a fairly loyal attitude toward the Common Market, partly I suspect, because there are many Frenchmen who realize that they need Britain if they are to maintain a balanced relationship with the Federal Republic of Germany.

QUESTION: Do you have any reservations about developments between the Russians and the Germans, particularly with regard to the approval of the German-Russian treaty?

This is a matter over which there were some differences of opinion in the State Department when I was still there. I, myself, was rather interested in trying out the possibilities of Ostpolitik while carefully keeping our wits about us. The U.S. and West and East Europe had pursued a policy of pretty harsh confrontation along that dividing line through Central Europe for about twenty years. That policy has not moved us one bit toward a resolution of the German and Berlin' questions; these are, by and large, about the only issues on which it is thinkable that the United States and the Soviet Union can have a nuclear war. In law, diplomacy, and politics, there is a fundamental difference between' rape and seduction. This twenty years of harsh confrontation has not carried us toward a settlement of the problems of Europe. 
I thought at least it might be worth using a little seduction, because by the end of that twenty-year period, the great gravitational pull of Central Europe clearly had moved to the West Germans. Consequently they did not need to be concerned about contamination from the East, as Chancellor Adenauer had feared almost passionately, and they could afford to explore new possibilities. I realize that some of my closest friends, some of the original NATO people in particular, are worried about it. I think it depends a good deal on how it is handled. I must confess that at the moment I am a bit concerned about the present status of the German-Russian Treaty before the Bundestag, because if that treaty is rejected and we enter a new period of crisis between the West Germans and the Russians during a period of American withdrawal, the West Germans might not be able to count on the support of the American people. This could be a very dangerous situation.

\section{QUESTION: What do you foresee as the future role for the United Nations?}

I consider the United Nations an indispensable network of international organizations. I think it has earned its pay hundreds of times over in all sorts of curious ways. Just to mention one, it was of tremendous importance to the United States that the Security Council of the United Nations be there at the moment of the Cuban Missile Crisis, so that we could refer that matter for debate. This enabled those involved to put questions of prestige into refrigeration for a few days and to gain time for each side to be in touch with the other to find some resolution to the problem. Generally speaking, on those issues where the Soviet Union and the United States have not been at each other's throats, in a bumbling and stumbling kind of way, the United Nations has done a pretty good job in preventing conflicts and in limiting conflicts that do break out.

There is one problem in the United Nations that concerns me and I am not sure there is much we can do about it, except through informal devices. Ten per cent of the world's population and five per cent of the contributions to the U.N. budget can now cast two-thirds of the votes in the General Assembly. There is an enormous gap between the voting power in the General Assembly and the responsibility in the real world, if I may put it that way. At a fairly recent general meeting of UNESCO, for example, six per cent of the budget voted yes; ninety-four per cent of the budget voted no; but the budget passed with a two-thirds vote. That tends to undermine the authority of the General Assembly. I hope that the mass of smaller countries will not try to take over the U.N. and produce ineffective and irresponsible resolutions of the sort that just are not acceptable in the real world.

There are potentionally another twenty or thirty of the so-called mini-states. The Maldive Islands were admitted some three years ago. I don't think they have been there since. They were there to be admitted, but their seat has been vacant, because they say they cannot afford a delegate, even though the General Assembly pays for the delegate. I hope the U.N. does not continue in that direction. We must try to find some way to establish informally, perhaps by means of a committee of 
the General Assembly, a kind of second chamber which would more accurately reflect the real responsibilities. This might involve having dual votes, that is, approval of important matters by this type of committee in addition to the General Assembly as a whole. That could be done without amendment of the charter. There is presently no chance of amending the charter, because these small countries are not going to amend it to their disadvantage. Nonetheless, I have no doubt that the United Nations is going to be an increasingly important organization. When you look ahead at the problems that we face-nuclear weapons, the environment, the population problem, and questions of that sort-it has a major job ahead of it. 